\title{
Geochemical investigations on the Mbuji-Mayi and Kundelungu megacryst suites (Democratic Republic of Congo)
}

\author{
M. Pivin, O. Féménias and D. Demaiffe \\ Laboratoire de Géochimie Isotopique et Géodynamique Chimique, DSTE (CP 160/02) \\ Université libre de Bruxelles U.L.B., 1050 Brussels, Belgium
}

Two kimberlite fields are known in Democratic Republic of Congo. The Mbuji-Mayi kimberlites are diamond-rich, they are located in the East Kasaï province and intrude the Archean $(>2.7 \mathrm{Ga})$ CongoKasaï craton. The diamond-poor Kundelungu kimberlites are situated on the Kundelungu Plateau (Shaba region) and crosscut a Paleoproterozoic basement $(\sim 1.9 \mathrm{Ga})$ belonging to the south-western extension of the Bangweulu block. These two kimberlite fields have been largely studied (Demaiffe et al, 1991) as well as the Mbuji-Mayi eclogite nodules (El Fadili \& Demaiffe, 1999) but their respective megacryst suites are still poorly known. The discrete nodule suites of both localities comprise typical pyrope, diopside and Mg-ilmenite megacrysts. Moreover, zircon, corundum, baddeleyite and chlorite megacrysts and rutile-silicate intergrowths have been found at Mbuji-Mayi and olivine, orthopyroxene and phlogopite megacrysts at Kundelungu.

Fig.1

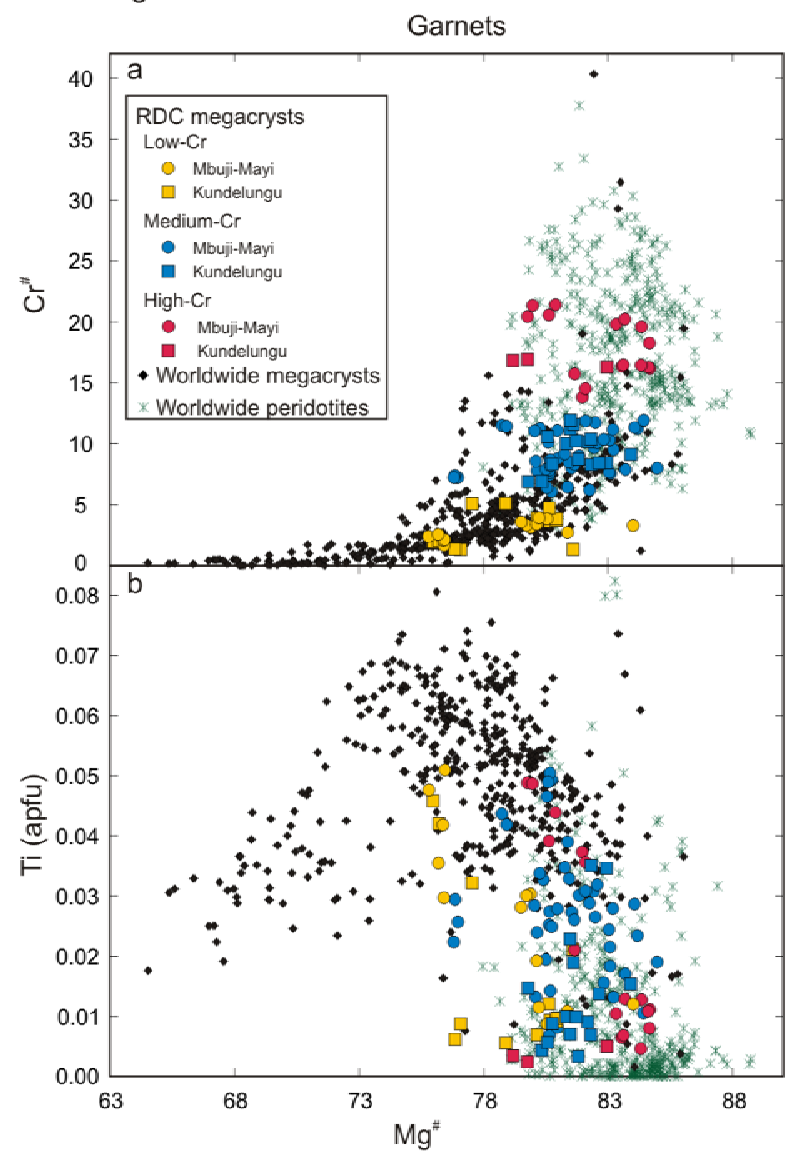

Preliminary investigations focus on major (WDS electron microprobe) and rare earth elements (LA-ICPMS) compositions of garnet megacrysts from both regions and clinopyroxene megacrysts from MbujiMayi.

\section{Major element compositions}

Three groups of pyrope are identified on the basis of their $\mathrm{Cr}$ content (fig. 1a): low- $\mathrm{Cr}\left(0.43-1.79 \mathrm{wt} \% \mathrm{Cr}_{2} \mathrm{O}_{3}\right.$; $\mathrm{Mg}^{\#}$ : 75.8-84.0); medium-Cr (1.93-4.12 $\mathrm{wt}^{\%} \mathrm{Cr}_{2} \mathrm{O}_{3}$; $\mathrm{Mg}^{\#}:$ 77.0-84.9) and high-Cr (4.44-6.89 wt $\% \mathrm{Cr}_{2} \mathrm{O}_{3}$; $\mathrm{Mg}^{\#}$ : 79.2-84.6). The three groups are recognized in both localities. There is no obvious geochemical difference between the compositions of the garnets of Mbuji-Mayi and Kundelungu.

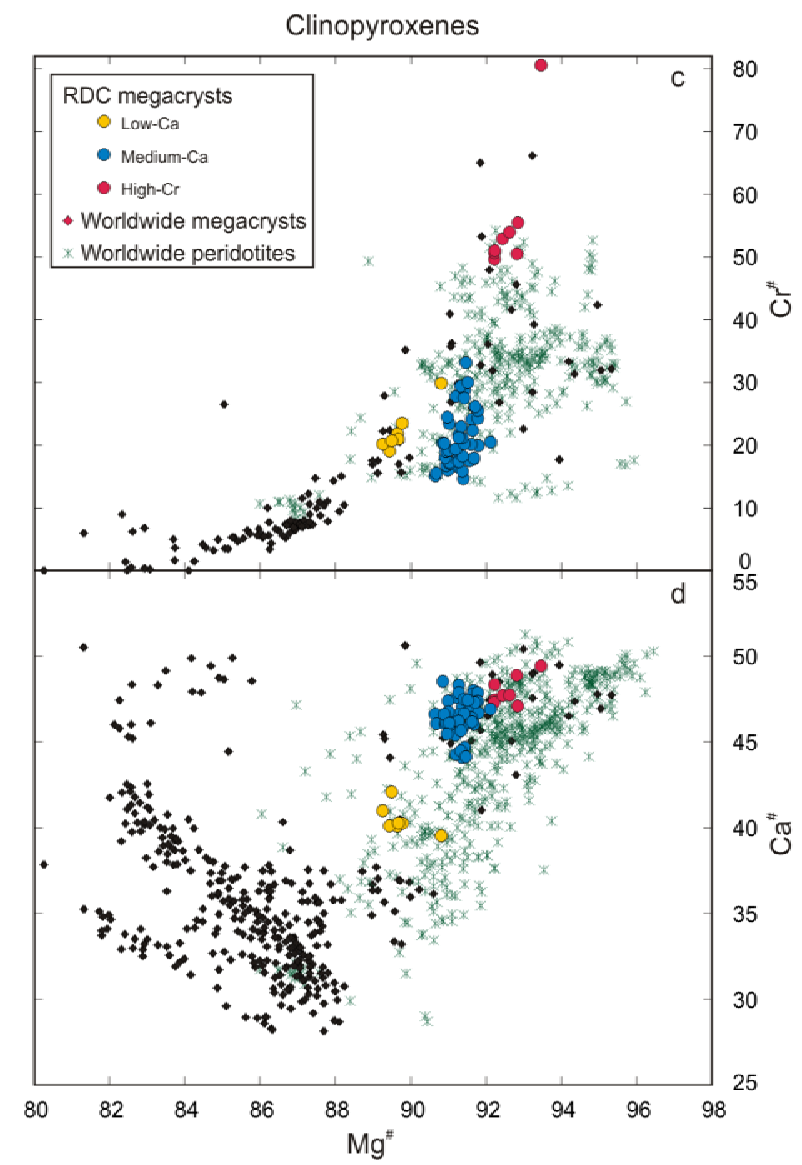


Moreover, many garnets, whatever their origin, size and/or composition, contain polymineral inclusions, principally K-rich hydrated minerals (phlogopite and amphibole) and Cr-spinels. These inclusions are commonly associated with a radial network of fractures. The presence of these inclusions in most garnets suggests a common process of formation.

Three diopside groups are distinguished at Mbuji-Mayi on the basis of their $\mathrm{Cr}$ and $\mathrm{Ca}$ contents (fig. 1c-d): low$\mathrm{Ca}\left(\mathrm{Ca}^{\#}:\right.$ 39.5-42.1; 0.61-0.92 $\left.\mathrm{wt}_{0} \mathrm{Cr}_{2} \mathrm{O}_{3}\right)$; medium-Ca $\left(\mathrm{Ca}^{\#}:\right.$ 44.1-48.5; 0.41-1.09 $\left.\mathrm{wt} \% \mathrm{Cr}_{2} \mathrm{O}_{3}\right)$ and high-Cr $\left(\mathrm{Ca}^{\#}: 47.1-49.4 ; 1.31-2.77 \mathrm{wt} \% \mathrm{Cr}_{2} \mathrm{O}_{3}\right)$.

The comparison of the RDC megacrysts with other megacryst suites worldwide (South Africa, Lesotho, Russia, USA for garnets and clinopyroxene and Australia, Canada, Siberia, Botswana and Namibia for garnets only; see *references), shows that RDC megacrysts display some peculiar major element features.

The RDC garnet megacrysts (fig.1a-b) do not show the usually observed trends of simultaneously decreasing $\mathrm{Cr}^{\#}[=\mathrm{Cr} /(\mathrm{Cr}+\mathrm{Al})]$ and $\mathrm{Mg}^{\#}[=\mathrm{Mg} /(\mathrm{Mg}+\mathrm{Fe})]$ or of inversely correlated $\mathrm{Ti}$ and $\mathrm{Mg}^{\#}$, which are commonly interpreted as typical fractional crystallisation trends (Garrison \& Taylor, 1980; Hops et al., 1992). The garnets from $\mathrm{RDC}$ are richer in $\mathrm{Cr}$ but poorer in $\mathrm{Ti}$ and $\mathrm{Fe}$ than those from other suites. The RDC clinopyroxene megacrysts (fig.1c-d) are enriched in $\mathrm{Mg}$ and $\mathrm{Cr}$ but depleted in $\mathrm{Ti}$ and $\mathrm{Fe}$ by comparison to others and they do not display the $\mathrm{Mg}^{\#}$ $\mathrm{Cr}^{\#}$ trend commonly seen in other localities. Furthermore, the negative correlation between $\mathrm{Ca}^{\#}$ $[=\mathrm{Ca} /(\mathrm{Mg}+\mathrm{Ca})]$ and $\mathrm{Mg}^{\#}$, widely observed in other suites (Bell et al., 2004), is absent from the RDC clinopyroxenes.

The comparison of the major element compositions of the RDC megacrysts with the minerals of peridotite xenoliths from kimberlites worldwide (Lesotho, Canada, USA, RDC, South Africa, see *references) brings some more features to light. The garnets from $\mathrm{RDC}$ are quite richer in $\mathrm{Fe}$ and $\mathrm{Ti}$ but poorer in $\mathrm{Cr}$ than those from the peridotite xenoliths (fig.1a-b). The Mbuji-Mayi clinopyroxenes are also enriched in $\mathrm{Fe}$ and $\mathrm{Ti}$; some of them are enriched in $\mathrm{Ca}$ and $\mathrm{Mg}$ by comparison to peridotitic clinopyroxene (fig.1c-d).

The RDC megacrysts appear thus to be intermediate between the megacrysts from other kimberlites and the kimberlite-derived peridotite xenoliths. They do not display the fractional crystallisation trends commonly observed in other megacryst suites and are enriched in $\mathrm{Fe}$ and $\mathrm{Ti}$ by comparison to peridotitic minerals.

\section{Trace element (REE) compositions}

Garnet megacrysts from RDC are quite poor in REE

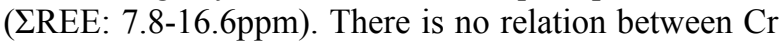
and REE contents. Most pyropes analysed display a "normal" pattern $\left((\mathrm{La} / \mathrm{Yb})_{N}=0.003-0.027\right)$ although some crystals are LREE enriched $\left(\mathrm{La}_{N} \sim 2.5-3\right)$ and/or display positive $\left(\mathrm{Eu} / \mathrm{Eu}^{*} \sim 1.35\right)$ or negative $\left(\mathrm{Eu} / \mathrm{Eu}^{*} \sim\right.$ 0.46) Eu anomalies (fig.2a). Similar anomalies have been observed in garnets from peridotite xenoliths and have been interpreted as resulting from variations in redox conditions during a metasomatic event (Griffin \& O’Reilly, 2007).

It is interesting to note that the patterns of the RDC garnet megacrysts are similar to those reported by Hoal et al. (1994) in the garnets from peridotite xenoliths of South Africa (fig.2a). The normal and sinusoidal REE profiles respectively represent garnets that were, or were not, reequilibrated with a LREE-enriched metasomatic agent (mantle fluid or melt?).

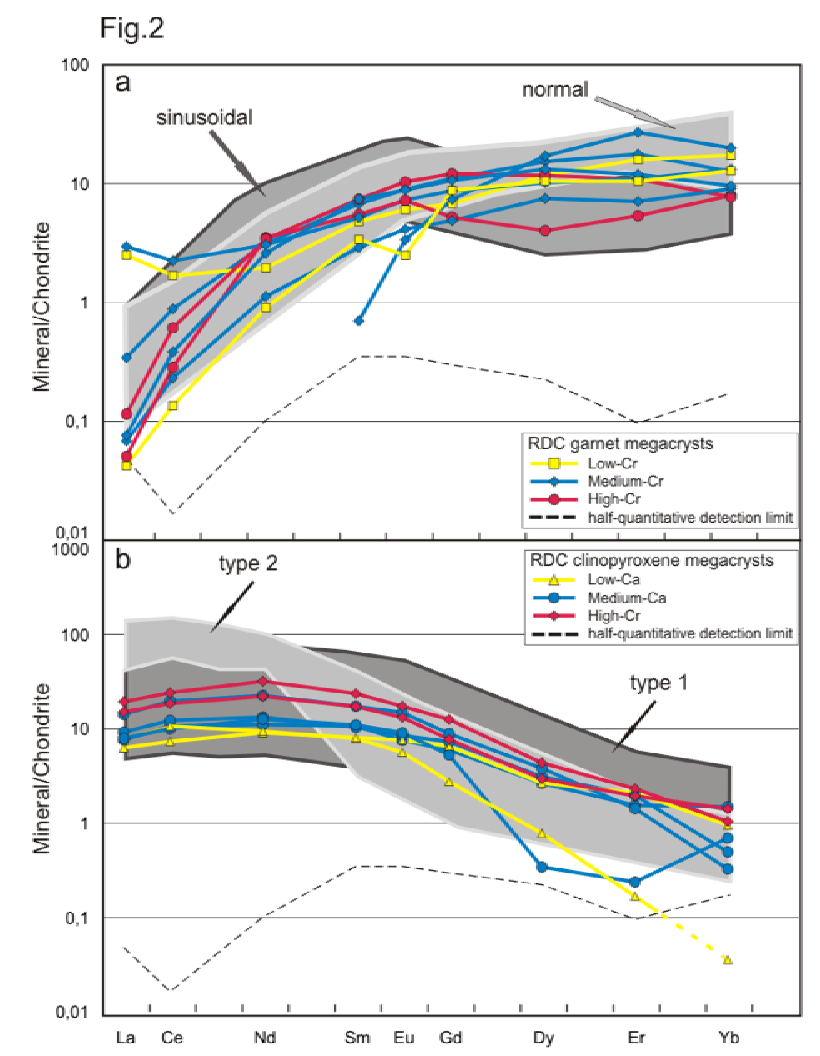

The RDC clinopyroxene megacrysts are also REE poor (LREE: $15.3-45.5 \mathrm{ppm}$ ) and display relative LREE enrichment $\left((\mathrm{La} / \mathrm{Yb})_{N}=5.1-43.2\right)$. There is a positive correlation between the REE and $\mathrm{Cr}$ contents of the diopsides. Again, the REE profiles of the diopside megacrysts are similar to those of the peridotitic clinopyroxenes (fig.2b).

In their study of the REE contents of the diopsides of garnet lherzolites from different Kaapvaal kimberlites, Gregoire et al. (2003) identified two types of profile: the types 1 and 2 (fig.2b). 
These two types of clinopyroxene are LREE enriched (type 2 is more enriched than type 1) and interpreted as minerals having crystallized from, or been completely equilibrated with, highly alkaline mafic silicate melts. For the type 1, which shows more similarities with the RDC diopsides, the melt is believed to be related to Group I kimberlite magmas. It has been shown that RDC kimberlites indeed belong to the Group I kimberlites (Weis \& Demaiffe, 1985).

The REE patterns of the RDC garnet and diopside megacrysts show similarities with some of the profiles recorded in the minerals of metasomatically modified peridotite xenoliths.

\section{Discussion and conclusions}

The differences in compositions between RDC megacrysts and those from other occurrences could be related to different modes of formation. Some megacryst suites could be associated to fractional crystallisation processes while the RDC megacrysts, which display chemical similarities with mantlederived minerals, could result from metasomatic transformation of deep mantle rocks. This assumption is strengthened by the probable two mantle metasomatisms observed in the RDC megacrysts: 1) the modal K-metasomatism represented by the presence of K-rich hydrated inclusions in garnets and 2) the cryptic Fe-Ti metasomatism.

\section{References}

*Bell, D.R., Moore, R.O., 2004. Deep chemical structure of the southern African mantle from kimberlite megacrysts, S. African J. Geol., 107, 59-80.

*Bell, D.R., Rossman, G.R., 1992. The distribution of hydroxyl in garnets from the subcontinental mantle of southern Africa, Contrib. Mineral. Petrol., 111, 161-178.

*Coussaert, N., 2005. Evaluation du degré d'équilibre dans les péridotites mantéliques du Lesotho, $\mathrm{PhD}$ Thesis, ULB, MRAC, Univ. de la Rochelle, 321pp.

*de Bruin, D., 2005. Multiple compositional megacryst groups from the Uintjiesberg and Witberg kimberlites, South Africa, S. African J. Geol., 108, 233-246.

Demaiffe, D., Fieremans, M., Fieremans, C., 1991. The kimberlites of Central Africa: a review, In: Kampunzu, A. and Lubala, T. (Eds): Magmatism in extensional structural setting: the Phanerozoic African plate. Springer-Verlag, 537-559.

*Eggler, D.H., Mc Callum, M.E., Smith, C.B., 1979. Megacryst assemblage in kimberlite from Northern Colorado and Southern Wyoming: Petrology, geothermometry-barometry and a real distribution, $2^{\text {nd }} I K C, 2,213-226$.

El Fadili, S., Demaiffe, D., 1999. Petrology of eclogite and granulite nodules from the Mbuji-Mayi kimberlites (Kasai, Congo): the significance of kyaniteomphacite intergrowths, In: Gurney, J. J. et al (Eds): Proc. $7^{\text {th }}$ IKC.,vol.1, Red Roof Des (CapeTown), 205-213.
*Garrison, J., Taylor, L.A., 1980. Megacrysts and xenoliths in kimberlite, Elliott County, Kentucky: A mantle sample from beneath the Permian Appalachian Plateau, Contrib. Mineral. Petrol., 75, 27-42.

Gregoire, M., Bell, D.R., Le Roex, A.P., 2003. Garnet lherzolites from the Kaapvaal craton (South Africa): trace element evidence for a metasomatic history, Journal of Petrology, 44, 629-657.

Griffin, W. L., O'Reilly, S.Y., 2007. Cratonic lithospheric mantle: Is anything subducted?, Episodes (IUGS), 30, 43-53.

*Gurney, J.J., Jakob, W.R.O., Dawson, J.B., 1979. Megacrysts from the Monastery kimberlite pipe, South Africa, $2^{\text {nd }} I K C 2,227-243$.

*Hearn, B. C., 2004. The Homestead kimberlite, central Montana, USA: mineralogy, xenocrysts, and uppermantle xenoliths, Lithos, 77, 473-491.

Hoal, K.E.O., Hoal, B.G., Erlank, A.J., Shimizu, N., 1994. Metasomatism of the mantle lithosphere recorded by rare earth elements in garnets, Earth Planet. Sci. Lett., 126, 303- 313.

*Hops, J. J., Gurney, J. J., Harte, B., 1992. The Jagersfontein Cr-poor megacryst suite - towards a model for megacryst petrogenesis, J. Volcanol. Geotherm. Res., 50, 143-160.

*Hunter, R.H., Taylor, L.A., 1984. Magma-mixing in the low velocity zone : kimberlitic megacrysts from Fayette County, Pennsylvania, Am. Mineral., 69, 16-29.

*Kampata, M. D., 1993. Minéralogie et géochimie des kimberlites du Haut plateau du Kundelungu (Shaba, Zaïre), PhD Thesis, UCL, Belgium, 248 pp.

*Kostrovitsky, S.I., Malkovets, V.G., Verichev, E.M., Garanin, V.K., Suvorova, L.F., 2004. Megacrysts from the Grib kimberlite pipe (Arkhangelsk Province, Russia), Lithos, 77, 511-523.

*Kostrovitsky, S.I., Verichev, E.M., Garanin, V.K., Suvorova, L.V., Aschepkov, I.V., Malkovets, V., Griffin, W.L., 2003. Megacrysts from Griba kimberlite pipe (Arkhangelsk Province), Proc. $8^{\text {th }}$ IKC., Victoria, BC, Canada.

*Menzies, A., Westerlund, K., Grütter, H., Gurney, J., Carlson, J., Fung, A., Nowicki, T., 2004. Peridotitic mantle xenoliths from kimberlites on the Ekati Diamond Mine property, N.W.T., Canada: major element compositions and implications for the lithosphere beneath the central Slave craton, Lithos, 77, 395-412.

*Mitchell, R.H., 1986. Kimberlites: mineralogy, geochemistry and petrology, Plenum Press, New York, $442 \mathrm{pp}$.

*Moore, A.E., Lock, N.P., 2001. The origin of mantlederived megacrysts and sheared peridotitesevidence from kimberlites in the northern LesothoOrange Free State (South Africa) and Botswana pipe clusters, S. African J. Geol., 104, 23-38.

*Nixon, P.H. (ed.), 1973. Lesotho Kimberlites, Capetown: Transvaal printers, Lesotho Nat Dev Corp, 350pp.

*Schulze, D.J., 1997. The significance of eclogite and Crpoor megacryst garnets in diamond exploration, Explor. Mining Geol, 6, 349-366.

Weis, D., Demaiffe, D., 1985. A depleted mantle source for kimberlites from Zaire: $\mathrm{Nd}, \mathrm{Sr}$ and $\mathrm{Pb}$ isotopic evidence, Earth and Planetary Science Letters, 73, 269-277. 